\title{
Article \\ Effects of the Fragrance Galaxolide on the Biomarker Responses of the Clam Ruditapes philippinarum
}

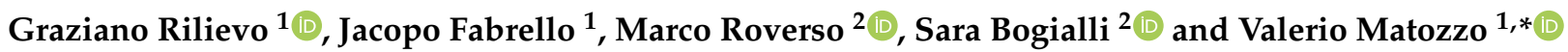 \\ 1 Department of Biology, University of Padova, Via Ugo Bassi 58/B, 35131 Padova, Italy; \\ graziano.rilievo@studenti.unipd.it (G.R.); jacopo.fabrello@unipd.it (J.F.) \\ 2 Department of Chemical Sciences, University of Padova, Via Marzolo 1, 35131 Padova, Italy; \\ marco.roverso@unipd.it (M.R.); sara.bogialli@unipd.it (S.B.) \\ * Correspondence: valerio.matozzo@unipd.it; Tel.: +39-049-8276201
}

Citation: Rilievo, G.; Fabrello, J.;

Roverso, M.; Bogialli, S.; Matozzo, V.

Effects of the Fragrance Galaxolide on the Biomarker Responses of the Clam Ruditapes philippinarum. J. Mar. Sci. Eng. 2021, 9, 509. https://doi.org/ 10.3390/jmse9050509

Academic Editor: Maria

Violetta Brundo

Received: 15 April 2021

Accepted: 7 May 2021

Published: 9 May 2021

Publisher's Note: MDPI stays neutral with regard to jurisdictional claims in published maps and institutional affiliations.

Copyright: (c) 2021 by the authors Licensee MDPI, Basel, Switzerland. This article is an open access article distributed under the terms and conditions of the Creative Commons Attribution (CC BY) license (https:/ / creativecommons.org/licenses/by/ $4.0 /)$.

\begin{abstract}
The musk fragrance Galaxolide ${ }^{\circledR}$ (HHCB) is widely used in personal care and household products. Its large use leads to a continuous release of the compound into aquatic environments. Although some studies on the presence of HHCB in ecosystems and biota have been conducted, limited data about its effects on organism biomarkers are available. This study aimed at investigating both cellular and biochemical effects of HHCB in the clam Ruditapes philippinarum. Mussels were exposed for 7, 14 and 21 days to $100 \mathrm{ng} / \mathrm{L}$ and $500 \mathrm{ng} / \mathrm{L}$ of HHCB in seawater, and the effects on haemocyte parameters and antioxidant enzyme activities in the gills and digestive gland were evaluated. In addition, the neurotoxic potential of HHCB and its capacity to cause oxidative damage to proteins were assessed. Overall, our results demonstrated that exposure to HHCB was able to induce changes in biomarker responses of mussels, mainly at the cellular level.
\end{abstract}

Keywords: fragrance; galaxolide; bivalves; mussels; biomarkers

\section{Introduction}

In recent decades, increasing attention has been paid to the adverse effects of pharmaceuticals and personal care products (PPCPs) on non-target species [1,2]. Among PPCPs, fragrances occur in aquatic ecosystems, and are believed to be ubiquitous due to their extensive use [1,3]. Nowadays, synthetic musks are the most widely used fragrances [3,4], being added to many households and personal care products, such as perfumes, shampoos, body lotions, laundry detergents and deodorants [5]. Synthetic musks are a family of cyclic compounds which can be divided into four main groups: nitro, polycyclic, macrocyclic and alicyclic $[4,6]$. Of them, polycyclic musk fragrances are the most widely used, with Galaxolide $^{\circledR}$ (HHCB) and Tonalide ${ }^{\circledR}$ (AHTN) as the most representative [4,7]. HHCB and AHTN cover about $95 \%$ of polycyclic musks available on the market [8]. In 2000, 1473 tons per year of HHCB and 358 tons per year of AHTN were estimated to be used in Europe [9], and concentrations over $4000 \mu \mathrm{g} / \mathrm{g}$ and 15,000 $\mathrm{\mu g} / \mathrm{g}$ of HHCB were found in US and Japan perfumes, respectively [7]. The external usage of the fragrances does not permit their transformation into more degradable by-products via metabolic pathways; thus, they enter the environment substantially unchanged [10]. The extensive use of these products leads to their massive apport into domestic sewages, and wastewater treatment plants (WWTPs) are often not able to degrade them completely [7,11]. Consequently, such compounds can be detected in WWTPs effluents, as well as in aquatic environments [2,7,12]. In addition to the environmental half-life of 15 and 67 days (in rivers) for HHCB and AHTN respectively [12], the daily use of these products leads to a relative pseudo-persistence in the aquifers [1]. Understandably, the higher concentrations of polycyclic musks are found in rivers and lakes near urban centres or WWTPs [13-15].

HHCB is generally detected at higher levels in aquatic ecosystems [2,3,7]. Obviously, the greatest concentrations were found in WWTPs influents, with levels as high as 
$45.1 \mu \mathrm{g} / \mathrm{L}$ [16]. Because of the ineffective degradation in treatment plants, concentrations up to $13.3 \mu \mathrm{g} / \mathrm{L}$ were found in WWTPs effluents [17]. In surface waters, levels of HHCB ranged from $<1 \mathrm{ng} / \mathrm{L}$ in absence of WWTPs effluents to units of $\mu \mathrm{g} / \mathrm{L}$ or even more where inputs of wastewater were present $[9,17,18]$. HHCB was also found in marine ecosystems, with concentrations ranging from 6 to $28 \mathrm{ng} / \mathrm{L}$ in estuarine and coastal environments [14], and from 0.09 to $4.8 \mathrm{ng} / \mathrm{L}$ in the German Bight in the North Sea [13]. HHCB has a log $\mathrm{K}_{\mathrm{OW}}$ coefficient of 5.9, which indicates a lipophilic nature and the potential to accumulate in organism tissues [19]. Indeed, detectable concentrations of the compound were found in several aquatic organisms, such as mussels, fish, aquatic birds, sharks, and marine mammals [20-25]. Interestingly, evidence of HHCB was found in human breast milk and in umbilical cord serum [26,27]. Details of HHCB features are summarised in Table 1.

Table 1. HHCB nomenclature and identification features and structural formula.

\begin{tabular}{ll}
\hline & Identification \\
\hline Trade name & Galaxolide ${ }^{\circledR}$ \\
Abbreviation & $\mathrm{HHCB}$ \\
CAS number & $1222-05-5$ \\
Molecular formula & $\mathrm{C}_{18} \mathrm{H}_{26} \mathrm{O}$ \\
Chemical name & $\begin{array}{l}1,3,4,6,7,8-H e x a h y d r o-4,6,6,7,8,8-h e x a- \\
\text { methyl-cyclopenta[g]2-benzopyran } \\
\text { Molecular weight }\end{array}$ \\
\hline
\end{tabular}

The toxicity of HHCB is still a matter of debate [7]. In the last few years, some studies on the effects of HHCB on aquatic organisms, including marine species, have been performed [7,28-32]. Both estrogenic and antiestrogenic effects were observed in biological models and aquatic organisms [7]. HHCB also affected larval and juvenile development of different organisms [33-37]. A concentration gradient experiment with the shrimp Palaemon varians showed an avoidance behaviour assumed by the animals from the compartments with higher levels of HHCB to the less concentrated ones [31]. Other studies also revealed the potential of HHCB to induce oxidative stress, enzyme activity alterations and genetic damage. Alterations in antioxidant enzymes activities were observed after exposure of the fish Carassius auratus and Danio rerio to the contaminant [38,39]. In a 21-d exposure test, HHCB (500 ng/L) caused oxidative stress (lipid peroxidation and protein carbonylation) and DNA strand breaks in the freshwater zebra mussel Dreissena polymorpha [40]. Oxidative stress, genetic damage and antioxidant enzymes activity alterations were also recorded in the Manila clam Ruditapes philippinarum exposed for 21 days to $0.005,0.05,0.5,5$ and $50 \mu \mathrm{g} / \mathrm{L}$ of HHCB [32]. Recently, the neurotoxic and endocrine-disrupting effects of the compound have been investigated in the same clam species [41]. In a study with Mytilus californianus, HHCB acted as a chemosensitizer, inhibiting the multixenobiotic resistance of the mussels [29]. Despite all these findings, information about sub-lethal effects due to long-term exposure of marine organisms to HHCB is lacking [32].

This study was performed to assess the effects of HHCB on biomarker responses of R. philippinarum. Biomarkers were measured in the haemocytes/haemolymph, gills and digestive gland. Biomarkers included total haemocyte count (THC), haemocyte diameter and volume, cell proliferation, cytotoxicity, lysozyme activity, activity of the antioxidant superoxide dismutase (SOD), catalase (CAT), glutathione reductase (GR), and glutathioneS-transferase (GST). Protein carbonyl content (PCC) was estimated as an oxidative damage biomarker. Lastly, measurement of the activity of acetylcholinesterase (AChE) and butyrylcholinesterase $(\mathrm{BChE})$ were used as neurotoxic biomarkers. Clam tissues analysed were the haemolymph, for evaluating haemocyte parameters [42-44], gills, being the first tissues in contact with seawater and pollutants, and digestive gland, for its accumulation and metabolism properties [45]. 


\section{Materials and Methods}

\subsection{Animals}

The clam R. philippinarum has been widely used as model organism in several ecotoxicological studies [46-50]. Specimens of $R$. philippinarum (mean shell length $\pm \mathrm{SD}=4.6 \pm 0.5 \mathrm{~cm}$ ) were collected in September 2020 in an unpolluted bivalve farming area in the southern basin of the Lagoon of Venice (Italy). They were kept in large aquaria with a sandy bottom and aerated sea water (salinity of $35 \pm 1 \mathrm{psu}$, temperature of $16 \pm 0.5^{\circ} \mathrm{C}$ ) for five days, before experiments. The clams were fed every two days with a microalgal mixture (Tetraselmis chuii and Phaeodactylum tricornutum).

\subsection{Experimental Design}

HHCB was purchased from LGC Standards S.r.l. (Milano, Italy). The stock solution (50 mg/L) was prepared in acetone (Sigma-Aldrich, Munich, Germany) and stored at $4{ }^{\circ} \mathrm{C}$ and in the dark for the duration of experiments.

The exposure of mussels was conducted in 30 L glass aquaria at the same thermohaline conditions used in the acclimatation period. Mussels (45 for each aquaria) were exposed to 0 +acetone (solvent control) and 100 and $500 \mathrm{ng} / \mathrm{L}$ of HHCB, with two replicates tanks for each experimental condition. The concentrations chosen in our study were previously tested by Parolini et al. [40], because similar concentrations are commonly found in Europe surface waters. In acetone control, the solvent was added at the highest concentration used in HHCB treatments $(10 \mu \mathrm{L} / \mathrm{L})$. Based on our preliminary observations (data not published), such concentration of methanol was unable to produce significant alterations in biomarker responses of clams with respect to a control condition without solvent. That is why we decided to prepare only one control (seawater + methanol). Seawater was renewed every two days, along with the nominal exposure concentrations and the microalgal mixture. Tissues were collected after 7,14 and 21 days of exposure.

\subsection{Tissue Collection}

At each exposure time, 12 specimens per aquaria were used ( 24 mussels for each experimental conditions). Animals were then divided into 6 pools of 4 specimens each, and haemolymph, gills and digestive glands were collected. Their haemolymph was collected from the anterior adductor muscle in a 1-mL plastic syringe and placed in Eppendorf tubes at $4{ }^{\circ} \mathrm{C}$. All haemocyte parameters were immediately measured, except for the lysozyme activity. Gills and digestive glands aliquots were frozen in liquid nitrogen and stored at $-20{ }^{\circ} \mathrm{C}$ until analyses. All the assays performed here had previously been validated in other studies $[43,45,50-55]$.

\subsection{Haemocyte Biomarkers}

THC and haemocyte diameter and volume were determined for each pool with a Scepter $^{\mathrm{TM}}$ 2.0 Automated Cell Counter (Millipore, FL, USA). Briefly, $20 \mu \mathrm{L}$ of haemolymph were added to $2 \mathrm{~mL}$ of Coulter Isoton diluent. THC was expressed as the number of haemocytes $\left(\times 10^{7}\right) / \mathrm{mL}$ of haemolymph, whereas cell diameter and cell volume were expressed as $\mu \mathrm{m}$ and $\mathrm{pL}$ (picolitres), respectively.

Since we demonstrated that haemocytes can divide in the haemolymph of R. philippinarum [56], cell proliferation was determined by means of a commercial kit (Cell proliferation Kit II, Roche). The results were normalised to the relative THC values and expressed as optical density at $450 \mathrm{~nm}\left(\mathrm{OD}_{450}\right)$.

Cytotoxicity was assessed with a commercial kit (Cytotoxicity Detection Kit, Roche), which is based on the evaluation of lactate dehydrogenase (LDH) activity. Results were normalised to the relative THC values and expressed as optical density at $490 \mathrm{~nm}\left(\mathrm{OD}_{490}\right)$.

Lysozyme activity was determined in the haemocyte lysate, higher enzymatic activity being detected in cells rather than in haemolymph [57]. From each pool, $500 \mu \mathrm{L}$ of haemolymph was centrifugated for $10 \mathrm{~min}$ at $3000 \times \mathrm{g}$. The supernatant was removed (subsequently used for the cytotoxicity assay described above) and $500 \mu \mathrm{L}$ of distilled water 
was added to obtain haemocyte lysate (HL). Briefly, $50 \mu \mathrm{L}$ of HL were added to $950 \mu \mathrm{L}$ of a $0.15 \%$ suspension of Micrococcus lysodeikticus (Sigma-Aldritch) in $66 \mathrm{mM}$ phosphate buffer ( $\mathrm{pH}$ 5.8). Lysozyme activity was determined with a spectrometric method proposed by Fisher et al. [58], where the decreasing of absorbance $(\Delta \mathrm{A} / \mathrm{min})$ was recorded at $450 \mathrm{~nm}$ for $5 \mathrm{~min}$ (lecture range of $30 \mathrm{~s}$ ) at room temperature [58]. A calibration curve was obtained from lysozyme standards, and a unit of lysozyme was defined as the amount of enzyme producing an activity equivalent to $1 \mu \mathrm{g}$ of lysozyme in the conditions described above. The results were expressed as $\mu \mathrm{g}$ of lysozyme per $\mathrm{mg}$ of proteins, the concentrations of which were quantified according to Bradford [59].

\subsection{Gill and Digestive Gland Biomarkers}

Gill and digestive gland samples were thawed and homogenised with an Ultra-Turrax homogeniser (model T8 basic, IKA) at $4{ }^{\circ} \mathrm{C}$ in $1 \mathrm{~mL}$ of homogenisation buffer, made of $10 \mathrm{mM}$ Tris-HCl buffer (pH 7.6), 0.15 M KCl, 0.5 M sucrose, $1 \mathrm{mM}$ EDTA and Protease Inhibitor Cocktail (P2714, Sigma-Aldrich). Samples were centrifuged at $12.000 \times g$ for $30 \mathrm{~min}$ at $4^{\circ} \mathrm{C}$, and supernatants (SN) were collected for the subsequent analyses. For each assay, $\mathrm{SN}$ protein concentrations were measured to normalize the results of enzyme activities [59].

SOD activity was measured both in gills and digestive gland according to the method proposed by Crapo et al. [60] with hypoxanthine, xanthine oxidase and cytochrome $\mathrm{c}$ as the reaction mixture [60]. Results are expressed as U SOD/mg protein, where one unit is the amount of sample producing 50\% inhibition in the assay conditions [60].

The Aebi method [61] was used to determine CAT activity in both tissues. Data are expressed as U CAT/mg protein, where one unit is the amount of sample that catalysed the dismutation of $1 \mu \mathrm{mol}$ of hydrogen peroxide per minute [61].

GR activity was measured using the method proposed by Smith et al. [62] both in gills and digestive gland following the reaction between glutathione (obtained from the reduction of its oxidate form by GR) and 5,5'-dithiobis(2-nitrobenzoic acid) (DTNB), which gives 5-thio-2-nitrobenzoic acid (TNB) as a product [62]. Results are expressed as U GR/mg protein, where one unit is the amount of enzyme that causes the reduction of $1.0 \mu \mathrm{mol}$ of DTNB to TNB at $25^{\circ} \mathrm{C}$.

GST activity, which was evaluated only in the digestive gland, was determined following the method of Habig et al. [63], following the reaction between 1-chloro-2,4-dinitrobenzene $(\mathrm{CDNB})$ and reduced glutathione [63]. Results are expressed as nmol/min/mg protein.

PCC was assessed with the method of Mecocci et al. [64] in both tissues, based on the reaction between the carbonyl groups - $\mathrm{CO}$ that might be on the proteins with 2,4-dinitrophenylhydrazide (DNPH). The carbonyl content is expressed as nmol of carbonylated proteins/mg total proteins [64].

AChE activity was measured in gills using the method of Ellman et al. [65]. The method relies on acetylthiocholine as substrate, which is hydrolysed to thiocholine and acetate by the enzyme. Then, thiocholine reacts with DTNB to give TNB, which is colorimetrically quantified [65]. Results are expressed as nmol $/ \mathrm{min} / \mathrm{mg}$ protein.

BChE activity was assessed according to Escartín et al. [66]. In this case the substrate is butyrylthiocholine. Results are expressed as $\mathrm{nmol} / \mathrm{min} / \mathrm{mg}$ protein.

\subsection{Statistical Analysis}

For all data, the normal distribution (Shapiro-Wilk's test) and homogeneity of the variance (Bartlett's test) were assessed. Results were statistically analysed using a two-way ANOVA analysis, with treatment and exposure time as predictors and the biomarkers as cases. For pairwise comparisons, a post-hoc test (Tukey's HSD test) was conducted when a significant effect of treatment or time*treatment interaction from the ANOVA test was recorded. The software used for the statistical analyses was STATISTICA 13.1 (StatSoft, Tulsa, OK, USA), and results are expressed as means \pm standard error. 


\section{Results}

\subsection{Haemocyte Parameters}

THC was significantly influenced only by treatment $(p<0.05)$ (Table 2), with a significant $(p<0.05)$ reduction on day 21 at $500 \mathrm{ng} / \mathrm{L}$, compared to the related control (Figure 1). Instead, no significant variations were detected for the diameter and the volume of haemocytes (Table 2; data not shown).

Table 2. Results of two-way ANOVA analysis for the haemocyte biomarkers measured in the haemolymph of Ruditapes philippinarum after exposure to HHCB. Statistically significant effects of the variables "time", "treatment" and "time*treatment interaction" are indicated in bold.

\begin{tabular}{ccccc}
\hline & Source of & \multicolumn{3}{c}{ Haemolymph } \\
\cline { 3 - 5 } & Variation & $\mathbf{F}$ & $d f$ & $p$-Value \\
\cline { 3 - 5 } THC & time & 2.78 & 2 & 0.072 \\
& treatment & 3.56 & 2 & $\mathbf{0 . 0 3 7}$ \\
& time*treatment & 1.97 & 4 & 0.115 \\
\hline \multirow{2}{*}{ Haemocyte } & time & 1.07 & 2 & 0.350 \\
diameter & Treatment & 0.79 & 2 & 0.461 \\
& time*treatment & 1.44 & 4 & 0.237 \\
\hline \multirow{2}{*}{ Haemocyte } & time & 3.14 & 2 & 0.053 \\
volume & treatment & 0.06 & 2 & 0.946 \\
& time*treatment & 0.35 & 4 & 0.844 \\
\hline \multirow{2}{*}{ Haemocyte } & time & 1.46 & 2 & 0.244 \\
proliferation & treatment & 7.04 & 2 & $\mathbf{0 . 0 0 2}$ \\
& time*treatment & 1.06 & 4 & 0.389 \\
\hline \multirow{2}{*}{ LDH } & time & 1.17 & 2 & 0.318 \\
& treatment & 0.54 & 2 & 0.584 \\
& time*treatment & 1.36 & 4 & 0.264 \\
\hline \multirow{2}{*}{ Lysozyme } & time & 0.59 & 2 & 0.559 \\
& treatment & 3.77 & 2 & $\mathbf{0 . 0 3 1}$ \\
\hline
\end{tabular}

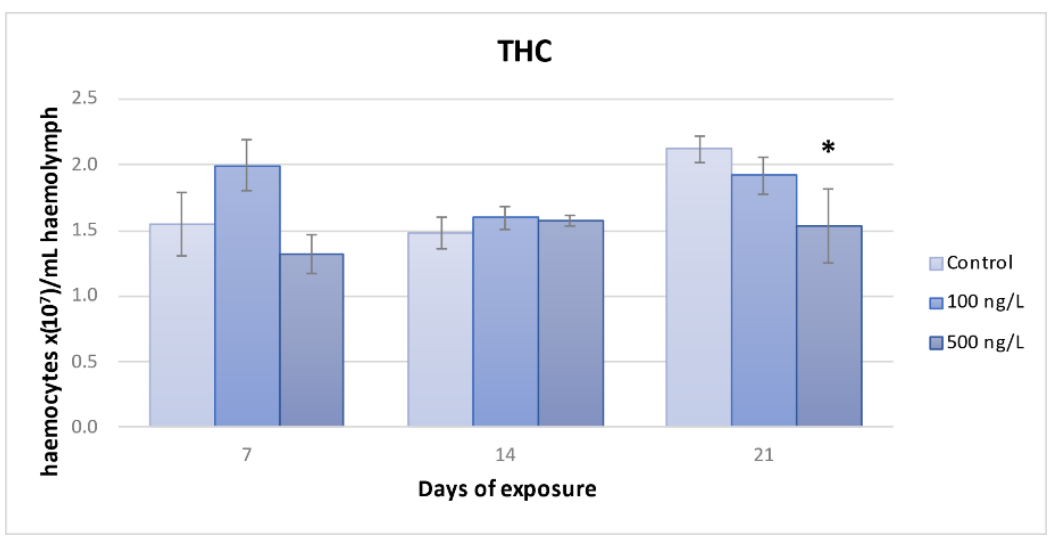

Figure 1. Total haemocyte count values in Ruditapes philippinarum after exposure for 7, 14 and 21 days to $100 \mathrm{ng} / \mathrm{L}$ and $500 \mathrm{ng} / \mathrm{L}$ of HHCB. The results are expressed as number of haemocytes $\times\left(10^{7}\right) / \mathrm{mL}$ of haemolymph and are reported as means \pm standard error; $\mathrm{n}=6$. Asterisks indicate significant differences compared to controls at the same time of exposure: ${ }^{*} p<0.05$.

A significant $(p<0.01)$ treatment-induced alteration in haemocyte proliferation was recorded (Table 2). The post-hoc test revealed a significant increase on days $7(p<0.05)$ and $21(p<0.01)$ in mussels exposed to $500 \mathrm{ng} / \mathrm{L}$ (Figure 2). 


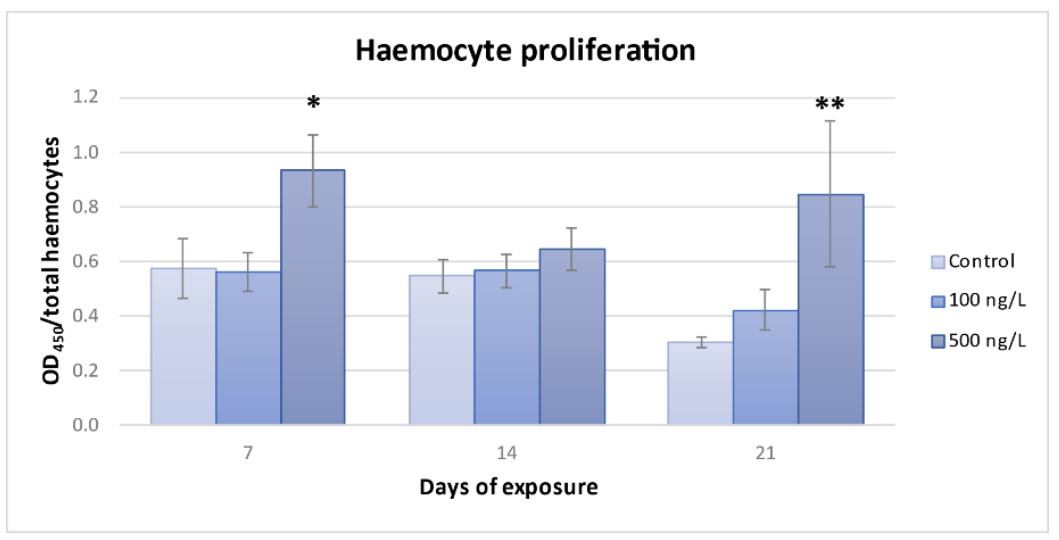

Figure 2. Haemocyte proliferation in Ruditapes philippinarum after exposure to $100 \mathrm{ng} / \mathrm{L}$ and $500 \mathrm{ng} / \mathrm{L}$ of HHCB for 7, 14 and 21 days. The results are expressed as $\mathrm{OD}_{450}$ and are reported as means \pm standard error; $\mathrm{n}=6$. Asterisks indicate significant differences compared to controls at the same time of exposure: ${ }^{*} p<0.05,{ }^{* *} p<0.01$.

No significant variations of LDH activity were recorded during the experiment (Table 2; figure not shown).

HL lysozyme activity was influenced significantly by treatment $(p<0.05)$ (Table 2$)$, but no significant differences were evidenced by Tukey's HSD test (figure not shown).

\subsection{Biochemical Parameters}

In gills, SOD activity was affected significantly by time of exposure $(p<0.001)$ and time ${ }^{*}$ treatment interaction $(p<0.001)$ (Table 3$)$. On day 7 , a significant increase of the enzymatic activity was recorded at $500 \mathrm{ng} / \mathrm{L}(p<0.01)$, whereas on day 14 , SOD activity was significantly decreased at both $100 \mathrm{ng} / \mathrm{L}(p<0.01)$ and $500 \mathrm{ng} / \mathrm{L}(p<0.001)$ (Figure 3). As for digestive gland SOD activity, only exposure time $(p<0.05)$ significantly affected enzyme activity (Table 3; figure not shown).

Gill CAT activity was influenced only by exposure time $(p<0.001)$ (Table 3; data not shown), whereas in digestive gland, CAT activity was affected by time $(p<0.001)$ and time ${ }^{*}$ treatment interaction $(p<0.01)$ (Table 3). Pair-wise comparisons showed a significant increase $(p<0.05)$ at $100 \mathrm{ng} / \mathrm{L}$ on day 7 , when compared to the related control (Figure 4).

No significant variations in GR activity were recorded in both gills and digestive gland of bivalves (Table 3; figure not shown).

Digestive gland GST activity was significantly influenced only by the time of exposure (Table 3; figure not shown).

In both tissues, no statistical differences in PCC values were found (Table 3; figure not shown).

AChE activity in gills was significantly influenced by time $(p<0.001)$ and treatment $(p<0.001)$ (Table 3). In particular, enzyme activity increased significantly $(p<0.01)$ at $100 \mathrm{ng} / \mathrm{L}$ on day 14 (Figure 5).

BChE activity was significantly influenced by time $(p<0.001)$ and time treatment interaction $(p<0.01)$ in gills, whereas in digestive gland the activity was modulated only by the factor time*treatment interaction $(p<0.01)$ (Table 3$)$. Despite these findings, no significant variations in the post-hoc test comparisons were observed related to the control groups (data not shown). 
Table 3. Results of two-way ANOVA analysis for the biomarkers measured in gills and digestive gland of Ruditapes philippinarum after exposure to HHCB. Statistically significant influences of the variables "time", "treatment" and "time*treatment" interaction are indicated in bold; n.m.: not measured.

\begin{tabular}{|c|c|c|c|c|c|c|c|}
\hline & \multirow{2}{*}{$\begin{array}{l}\text { Source of } \\
\text { Variation }\end{array}$} & \multicolumn{3}{|c|}{ Gills } & \multicolumn{3}{|c|}{ Digestive Gland } \\
\hline & & F & $d f$ & $p$-Value & F & $d f$ & $p$-Value \\
\hline \multirow{3}{*}{ SOD } & time & 36.22 & 2 & 0.000 & 3.21 & 2 & 0.050 \\
\hline & treatment & 1.18 & 2 & 0.316 & 0.51 & 2 & 0.604 \\
\hline & time treatment & 11.62 & 4 & 0.000 & 2.40 & 4 & 0.064 \\
\hline \multirow{3}{*}{ CAT } & time & 36.05 & 2 & 0.000 & 9.16 & 2 & 0.000 \\
\hline & treatment & 0.83 & 2 & 0.443 & 0.05 & 2 & 0.955 \\
\hline & time*treatment & 2.23 & 4 & 0.081 & 5.47 & 4 & 0.001 \\
\hline \multirow{3}{*}{ GR } & time & 1.72 & 2 & 0.191 & 2.58 & 2 & 0.087 \\
\hline & treatment & 0.70 & 2 & 0.503 & 2.63 & 2 & 0.083 \\
\hline & time*treatment & 0.84 & 4 & 0.509 & 2.38 & 4 & 0.066 \\
\hline \multirow{3}{*}{ GST } & time & n.m. & n.m. & n.m. & 7.58 & 2 & 0.001 \\
\hline & treatment & n.m. & n.m. & n.m. & 2.48 & 2 & 0.095 \\
\hline & time*treatment & n.m. & n.m. & n.m. & 2.19 & 4 & 0.085 \\
\hline \multirow{3}{*}{ PCC } & time & 0.33 & 2 & 0.718 & 0.16 & 2 & 0.856 \\
\hline & treatment & 1.03 & 2 & 0.366 & 0.84 & 2 & 0.436 \\
\hline & time*treatment & 1.10 & 4 & 0.370 & 1.11 & 4 & 0.366 \\
\hline \multirow{3}{*}{ AChE } & time & 14.53 & 2 & 0.000 & n.m. & n.m. & n.m. \\
\hline & treatment & 13.31 & 2 & 0.000 & n.m. & n.m. & n.m. \\
\hline & time $e^{*}$ reatment & 1.63 & 4 & 0.184 & n.m. & n.m. & n.m. \\
\hline \multirow{3}{*}{ BChE } & time & 107.10 & 2 & 0.000 & 2.28 & 2 & 0.114 \\
\hline & treatment & 1.27 & 2 & 0.290 & 1.08 & 2 & 0.348 \\
\hline & time*treatment & 5.14 & 4 & 0.002 & 4.67 & 4 & 0.003 \\
\hline
\end{tabular}

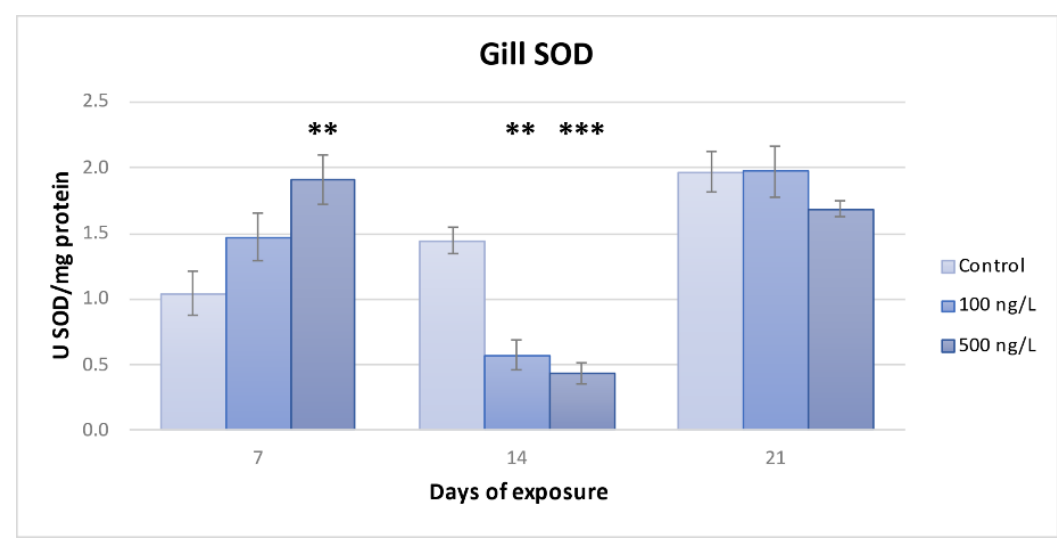

Figure 3. Superoxide dismutase activity in the gills of Ruditapes philippinarum after exposure for 7, 14 and 21 days to $100 \mathrm{ng} / \mathrm{L}$ and $500 \mathrm{ng} / \mathrm{L}$ of HHCB. The results are expressed as U/mg of proteins and are reported as means \pm standard error; $\mathrm{n}=6$. Asterisks indicate significant differences compared to controls at the same time of exposure: ${ }^{* *} p<0.01,{ }^{* * *} p<0.001$. 


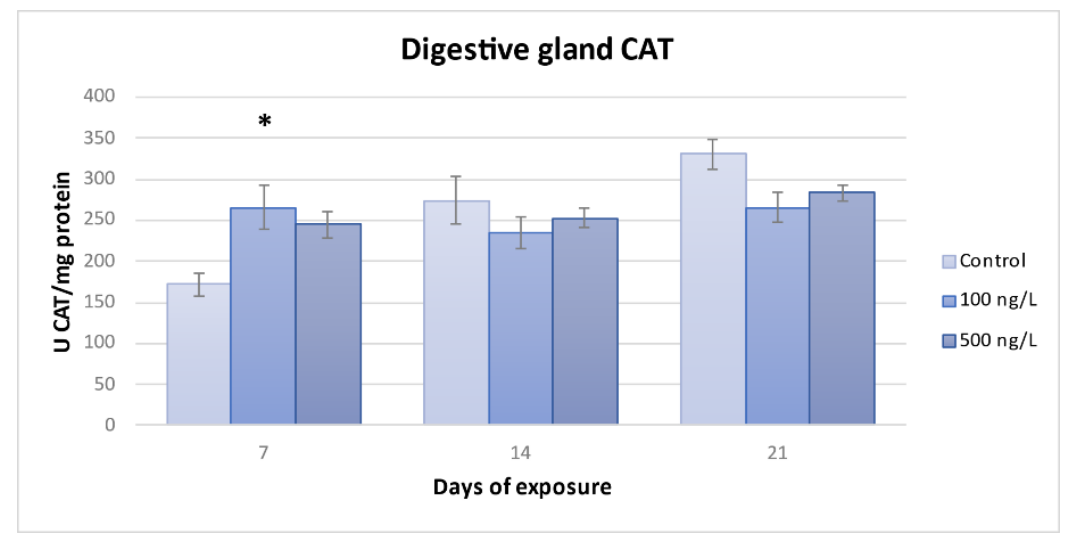

Figure 4. Catalase activity in the digestive gland of Ruditapes philippinarum after exposure for 7, 14 and 21 days to $100 \mathrm{ng} / \mathrm{L}$ and $500 \mathrm{ng} / \mathrm{L}$ of HHCB. The results are expressed as U/mg of proteins and are reported as means \pm standard error; $n=6$. Asterisks indicate significant differences compared to controls at the same time of exposure: ${ }^{*} p<0.05$.

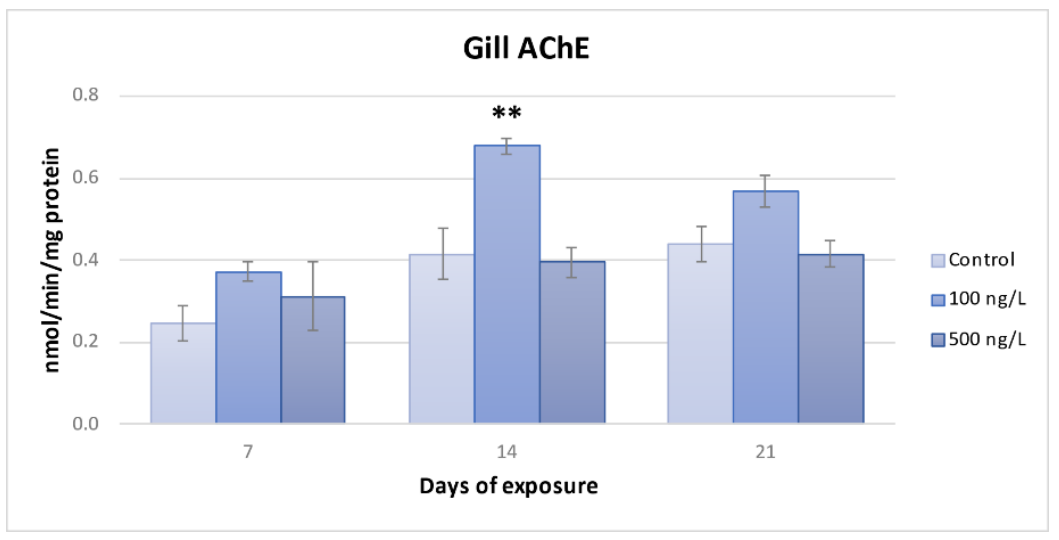

Figure 5. Acetylcholinesterase activity values in the gills of Ruditapes philippinarum after exposure to $100 \mathrm{ng} / \mathrm{L}$ and $500 \mathrm{ng} / \mathrm{L}$ of HHCB for 7, 14 and 21 days. The results are expressed as $\mathrm{nmol} / \mathrm{min} / \mathrm{mg}$ of proteins and are reported as means \pm standard error; $n=6$. Asterisks indicate significant differences compared to controls at the same time of exposure: ${ }^{* *} p<0.01$.

\section{Discussion}

HHCB is a synthetic musk fragrance widely used in household and personal care products [4]. Its massive use along with ineffective WWTPs treatments leads to a continued release of the compound into aquatic environments $[1,4,9]$. Since it is considered an emerging pollutant like other PPCPs, HHCB has been subjected to some ecotoxicological investigations, especially in aquatic organisms [7]. However, only a few studies have been conducted on marine organisms, and toxicological information regarding HHCB in the marine environment is still lacking [32]. This study aimed to assess whether HHCB may cause oxidative, neurotoxic or immunotoxic damages to the clam R. philippinarum. Two concentrations of HHCB, namely 100 and $500 \mathrm{ng} / \mathrm{L}$, were tested in a 21-day semi-static exposure.

The mollusc immune system relies on haemocytes, which exert a defensive action against pathogens and xenobiotics [67]. Strong environmental variations or exposure to pollutants may cause negative effects on the immune system and may lead to a higher sensibility of animals to pathogens [68]. Pollutants such as heavy metals, organotin compounds and polycyclic aromatic hydrocarbons have been shown to elicit an immunotoxic effect on molluscs $[42,69]$. Several haemocyte parameters (=immunomarkers) were measured in this study to evaluate whether HHCB might cause immunomodulation in Manila clams. To the best of our knowledge, there are no data on the effects of this contaminant on the immune system of marine animals. 
THC is one of the most used immunomarkers to assess negative cell effects of pollutants in molluscs [70]. An increase in circulating haemocyte number may be a result of either augmented cell proliferation or increased migration of cells from peripherical tissues to the haemolymph [71]. On the other hand, haemocyte migration from the haemolymph to other tissues can result in a reduction in THC. Nevertheless, a decrease in THC may be a consequence of cell death [71]. In this study, exposure to $500 \mathrm{ng} / \mathrm{L} \mathrm{HHCB}$ induced a significant reduction of THC in R. philippinarum at the end of the exposure. Other studies demonstrated the same pattern after exposure of Manila clams to PPCPs. For example, a reduction in THC was detected in molluscs after chronic exposure to ibuprofen [44] and triclosan [43]. In this study, we assume that THC reduction might be caused by haemocyte migration from haemolymph to other tissues. We discarded the hypothesis of damage to haemocytes (i.e., cell death) as no significant variations in LDH activity were detected (LDH is a biomarker of cell membrane stability). However, higher haemocyte proliferation recorded in the mussels exposed for 21 days to $500 \mathrm{ng} / \mathrm{L}$ did not induce an increase in THC values. Probably, increases in cell proliferation fixed only partially the substantial reduction of THC levels at the same experimental condition (see below).

As for the diameter and volume of haemocytes, no significant differences were observed in this study. Generally, an increase in these parameters may be due to increased phagocytic activity, whereas a reduction may be a consequence of cell membrane damage and cytoplasm leaks [43].

The cell proliferation assay showed an increase in haemocyte proliferation at $500 \mathrm{ng} / \mathrm{L}$ after 7 and 21 days of exposure. It was shown that Manila clam haemocytes have the capability to divide in the haemolymph [56]. Comparing such results with those of THC assay, an increasing trend in cell proliferation associated with reductions in THC values after 7 and 21 days can be highlighted at the same experimental conditions. However, the decreased THC value on day 7 was not statistically significant. These might be explained by the raised proliferation of haemocytes, which might have compensated for the THC reduction. Instead, on day 21 the augmented proliferation might not be enough to face the reduction in cell number. This pattern of variation was also shown in another study on R. philippinarum, where exposure to $1000 \mu \mathrm{g} / \mathrm{L}$ ibuprofen caused a reduction in THC values along with an increase in haemocytes proliferation [44]. On the contrary, a reduction of both THC and cell proliferation was observed after exposure of clams to triclosan [43].

$\mathrm{LDH}$ is a lysosomal enzyme that can be released in serum/haemolymph by damaged cells [43]. Our results demonstrated the absence of cytotoxicity in haemocytes of $R$. philippinarum after exposure to HHCB. In previous studies, cell membrane destabilisation was found after exposure of clams to triclosan (300, 600 and $900 \mathrm{ng} / \mathrm{L})$ and ibuprofen $(1000 \mu \mathrm{g} / \mathrm{L})[43,44]$.

Lysozyme is the main bacteriolytic agent able to digest both Gram-positive and Gramnegative bacteria. A reduced lysozyme activity may cause a reduction in immunosurveillance [42]. Being synthesised in haemocytes, lysozyme may be released in the haemolymph during phagocytosis, to promote pathogen degradation [72]. Generally, higher levels of enzyme activity are found in cells than in haemolymph [57]. For that reason, here we evaluated lysozyme activity in haemocyte lysate. However, no significant variations in lysozyme activity were revealed by the post-hoc comparison test. In other studies, no significant effects on lysozyme activity were observed after exposure of $R$. philippinarum to triclosan [43], whereas exposure to 100 and $1000 \mu \mathrm{g} / \mathrm{L}$ of ibuprofen determined a decreased lysozyme activity in cell-free haemolymph [73].

Reactive oxygen species (ROS) may cause damage in cell structures [74]. Exposure to several pollutants may enhance ROS production in an organism's tissues, overwhelming the antioxidant capacities of the cells and resulting in oxidative stress [75]. Thus, the measurement of antioxidant enzyme activity is used as a biomarker of oxidative stress. It should be considered, however, that the activity of such enzymes is influenced by biological factors, such as age and reproduction period, and environmental factors such as $\mathrm{pH}$, temperature and dissolved oxygen [74]. In this study, the antioxidant enzymes analysed were SOD, CAT, GR and GST. 
SOD is a metalloenzyme involved in the dismutation of superoxide radical to oxygen and hydrogen peroxide [60]. SOD, working in synergy with CAT, represents one of the most important antioxidant defences. CAT further transforms hydrogen peroxide (another ROS) into water and gaseous oxygen [61]. After HHCB exposure, differences in SOD activity were observed only in clam gills. Exposure for 7 days to $500 \mathrm{ng} / \mathrm{L}$ of HHCB induced a significant increase of SOD activity. An opposite trend was recorded after 14 days of exposure to both concentrations tested. These results suggested that HHCB might have induced SOD activity in the first 7 days of exposure probably to counteract a ROS increase in tissues, at least at the highest concentration tested. On day 14, enzyme activity strongly decreased, suggesting a substantial reduction of the antioxidant defences. At the end of exposure, however, SOD activity returned to control levels, similarly to what was observed in previous studies [38,39]. In our study, the non-linear pattern of variation of SOD activity was not confirmed by that of CAT activity. Indeed, in gills there were no significant differences in enzyme activity. Based on SOD activity results, an increase in CAT activity was expected at least at $500 \mathrm{ng} / \mathrm{L}$ of HHCB on day 7. We hypothesised that hydrogen peroxide produced by increased SOD activity was transformed by other enzymes, such as glutathione peroxidase (which was not evaluated in this study). In the digestive gland, CAT activity showed a significant increase at $100 \mathrm{ng} / \mathrm{L} \mathrm{HHCB}$ after 7 days of exposure but returned to control levels by the end of the exposure period. Based on the results obtained in the present study, we can state that HHCB can only partially cause an oxidative stress status in clams, under the experimental conditions tested at least. To the best of our knowledge, there are no data concerning the effects of HHCB on SOD and CAT activities in marine organisms. In a study with D. rerio, concentrations of 0.37 and $0.17 \mathrm{mg} / \mathrm{L}$ induced an increase in SOD activity on the second day of exposure [39]. In the liver of the fish C. auratus, exposure to 15,75 and $150 \mu \mathrm{g} / \mathrm{L}$ HHCB caused an increase in SOD activity after 14 days of exposure and in CAT activity after 14 and 21 days [38]. As for the clam R. philippinarum, triclosan was shown to elicit an increase in gills SOD activity and a reduction in the digestive gland at the concentrations of 600 and $900 \mathrm{ng} / \mathrm{L}$ [45]. Milan et al. [73] demonstrated a decrease in SOD activity in the digestive gland from bivalves exposed for 5 and 7 days to 100 and $1000 \mu \mathrm{g} / \mathrm{L}$ of ibuprofen. Exposure to different pharmaceuticals ( $15 \mu \mathrm{g} / \mathrm{L}$ of carbamazepine, diclofenac and ibuprofen) caused different patterns of variation of SOD and CAT activities over time, both in the gills and digestive gland of R. philippinarum [49]. However, the clams also showed a general recovery capability of the antioxidant defences at the end of the exposure time [49].

Glutathione is a peptide able to conjugate several harmful compounds, including ROS [62]. To carry out its function, it needs the activities of other enzymes, such as GR, which makes new glutathione by reducing its oxidised form to the reactive one, whereas GST allows glutathione to bond with harmful reactive species in order to remove them. In this study, no significant changes in GR or GST activity were recorded in tissues of $R$. philippinarum. Our results are in contrast with those of Ehiguese et al. [32], who exposed the clams to different HHCB concentrations $(0.005,0.05,0.5,5$ and $50 \mu \mathrm{g} / \mathrm{L})$. In the digestive gland, the authors reported a reduction in GR activity at all the concentrations tested at each exposure time (3, 7, 14 and 21 days) [32]. Moreover, GST increased at all HHCB concentrations and all exposure times (with the only exception of the lowest concentration at 7 days) [32]. In the light of those results, the authors highlighted the potential of HHCB to induce oxidative stress in R. philippinarum [32]. The inconsistency between our results and those reported here [32] indicates that further analyses are necessary to better clarify the role of HHCB in promoting oxidative stress by modulating GR and GST activity. In another study on PPCPs, Trombini et al. [49] observed an initial increase of both enzyme activities followed by a reduction over time after exposure for 14 days of $R$. philippinarum to $15 \mu \mathrm{g} / \mathrm{L}$ carbamazepine, $15 \mu \mathrm{g} / \mathrm{L}$ diclofenac and $15 \mu \mathrm{g} / \mathrm{L}$ ibuprofen.

ROS and other oxidant agents may cause oxidation and modification of the proteins, such as the formation of carbonyl groups [75]. Carbonylation may exert different effects on proteins, for instance leading to their aggregation, inactivation or degradation [69]. Pollutants, which 
may enhance ROS production in cells, may therefore cause protein carbonylation $[69,74,75]$. Quantifying the amount of carbonyl groups in proteins is an indicator of possible oxidative damage induced by a contaminant [69]. In this study, PCC levels were not influenced by exposure to HHCB, in both tissues of $R$. philippinarum. In D. polymorpha, exposure to $500 \mathrm{ng} / \mathrm{L}$ HHCB induced an increase in PCC after 21 days [40]. Based on our study, we can exclude that $\mathrm{HHCB}$ causes oxidative damage to $R$. philippinarum proteins.

$\mathrm{AChE}$ and $\mathrm{BChE}$ are cholinesterases, which are a class of ubiquitous serine hydrolases that remove acetylcholine from the synaptic cleft [76,77]. Acetylcholine is a neurotransmitter that works between the synaptic junctions and is responsible for the nervous signal transmission to cholinergic receptors [78]. Once the signal is transmitted, AChE hydrolyses acetylcholine in choline and acetic acid [79], giving the end of the neural signal transmission [78]. This neurotransmission system is widely present in organisms, even if is not well characterized in invertebrates [80]. Inhibition of AChE activity may result in acetylcholine accumulation in the synaptic cleft, provoking a continued stimulation of cholinergic receptors [78], with negative consequences, such as convulsions and paralysis in the worst cases [80]. In previous studies, AChE inhibition was widely used as a neurotoxic biomarker to evaluate the effects of carbamate and organophosphate pesticides on fish and invertebrates [81]. Recently, AChE activity measurement has also been used to define the neurotoxic potential of other contaminants, such as detergents, heavy metals, and polycyclic aromatic hydrocarbon [82]. In this study, AChE activity was determined to evaluate a possible neurotoxic effect of $\mathrm{HHCB}$ on $R$. philippinarum. We evaluated AChE activity only in clam gills because they are the first tissue in contact with waterborne contaminants, and because cholinesterases activity is greater in such tissue than others [83]. In this study, a significant increase of AChE activity was found at $100 \mathrm{ng} / \mathrm{L}$ on day 14, suggesting a reaction of the organisms to mitigate a possible neurotoxic effect of HHCB. In a recent study, inhibition of AChE activity has been observed in clams exposed to different HHCB concentrations (from 0.005 to $50 \mu \mathrm{g} / \mathrm{L}$ ) at different exposure times [41], suggesting the capability of HHCB to influence AChE activity in tissues of the clam R. philippinarum. Conversely, our study does not allow us to affirm that HHCB is neurotoxic to $R$. philippinarum. In a previous study, Milan et al. [73] demonstrated that exposure to ibuprofen caused a different pattern of variation in enzyme activity over time. Trombini et al. [45] observed an increase in enzyme activity in the digestive gland after exposure of clams to $15 \mu \mathrm{g} / \mathrm{L}$ diclofenac, whereas all the pharmaceuticals tested (carbamazepine, diclofenac and ibuprofen) caused an increase in gills [49]. A significant decline of AChE activity, instead, was registered in the bivalve gills after exposure to 300 and $900 \mathrm{ng} / \mathrm{L}$ triclosan for 7 days.

While AChE rapidly hydrolyses acetylcholine, BChE (also known as nonspecific cholinesterase or pseudocholinesterase) does not have a well-identified natural substrate [76,77]. It is hypothesised that BChE acts as a scavenging enzyme in natural compound detoxification [76] and preserves $\mathrm{AChE}$ by substituting it in the reaction with toxic organophosphate [84]. It has been suggested that BChE might play a back-up role when AChE activity in neurotransmission is insufficient, although more experimental evidence is needed [85]. In marine invertebrates, BChE activity along with AChE was evaluated to assess the neurotoxicity of pollutants [76,83,86,87]. Herein, we evaluated the activity of $\mathrm{BChE}$ in the gills and digestive gland as a neurotoxic biomarker of HHCB exposure in $R$. philippinarum. The results indicated that treatment did not induce statistical changes in the enzyme activity in both tissues, suggesting that HHCB was not able to promote neurotoxicity in clams. Since there are no data about HHCB effects on BChE activity in aquatic organisms, further studies are required in order to better clarify this aspect. In previous studies, BChE activity was measured in molluscs exposed to pesticides and organophosphorus compounds [66,86,87].

\section{Conclusions}

Our results suggest that HHCB can partially affect biomarker responses of $R$. philippinarum. As for haemocytes, HHCB was shown to influence THC, haemocyte proliferation 
and HL lysozyme activity, mainly at the highest concentration tested. With regard to antioxidant enzymes, modulations of SOD and CAT activities were observed, whereas no significant changes in GR and GST activities were recorded. Based on these results and those of PCC, AChE and BChE assays, we can exclude HHCB-mediated oxidative stress/damage and neurotoxicity in clams. Considering the controversial results available in the literature, we think that more efforts should be addressed at evaluating the effects of fragrances on bivalves, as well as on other aquatic species.

Author Contributions: Conceptualization, G.R., J.F., M.R., S.B. and V.M.; methodology, G.R., J.F., M.R., S.B. and V.M.; formal analysis and investigation, G.R. and J.F.; data curation, G.R., J.F., M.R., S.B. and V.M.; writing-original draft preparation, G.R., J.F., M.R., S.B. and V.M.; writing-review and editing, G.R., J.F., M.R., S.B. and V.M. All authors have read and agreed to the published version of the manuscript.

Funding: This research received no external funding.

Institutional Review Board Statement: Not applicable.

Informed Consent Statement: Not applicable.

Conflicts of Interest: The authors declare no conflict of interest.

\section{References}

1. Daughton, C.G.; Ternes, T.A. Pharmaceuticals and personal care products in the environment: Agents of subtle change? Environ. Health Perspect. 1999, 107, 907-938. [CrossRef]

2. Montes-Grajales, D.; Fennix-Agudelo, M.; Miranda-Castro, W. Occurrence of personal care products as emerging chemicals of concern in water resources: A Review. Sci. Total Environ. 2017, 595, 601-614. [CrossRef]

3. Brausch, J.M.; Rand, G.M. A review of personal care products in the aquatic environment: Environmental concentrations and toxicity. Chemosphere 2011, 82, 1518-1532. [CrossRef]

4. Vallecillos, L.; Borrull, F.; Pocurull, E. Recent approaches for the determination of synthetic musk fragrances in environmental samples. TRAC Trends Anal. Chem. 2015, 72, 80-92. [CrossRef]

5. Nakata, H.; Hinosaka, M.; Yanagimoto, H. Macrocyclic-, polycyclic-, and nitro musks in cosmetics, household commodities and indoor dusts collected from Japan: Implications for their human exposure. Ecotoxicol. Environ. Saf. 2015, 111, 248-255. [CrossRef]

6. Kraft, P. Aroma Chemicals IV: Musks. In Chemistry and Technology of Flavours and Fragrances; Wiley Blackwell: Oxford, UK, 2009; pp. 143-168, ISBN 9781444305517.

7. Rainieri, S.; Barranco, A.; Primec, M.; Langerholc, T. Occurrence and toxicity of musks and UV filters in the marine environment. Food Chem. Toxicol. 2017, 104, 57-68. [CrossRef]

8. Gatermann, R.; Biselli, S.; Hühnerfuss, H.; Rimkus, G.G.; Franke, S.; Hecker, M.; Kallenborn, R.; Karbe, L.; König, W.A. Synthetic musks in the environment. Part 2: Enantioselective transformation of the polycyclic musk fragrances HHCB, AHTN, AHDI, and ATII in Freshwater Fish. Arch. Environ. Contam. Toxicol. 2002, 42, 447-453. [CrossRef]

9. Villa, S.; Assi, L.; Ippolito, A.; Bonfanti, P.; Finizio, A. First evidences of the occurrence of polycyclic synthetic musk fragrances in surface water systems in italy: Spatial and temporal trends in the Molgora River (Lombardia Region, Northern Italy). Sci. Total Environ. 2012, 416, 137-141. [CrossRef]

10. Ternes, T.A.; Joss, A.; Siegrist, H. Scrutinizing pharmaceuticals and personal care products in wastewater treatment. Environ. Sci. Technol. 2004, 38, 392A-399A. [CrossRef] [PubMed]

11. Bester, K. Analysis of musk fragrances in environmental samples. J. Chromatogr. A 2009, 1216, 470-480. [CrossRef] [PubMed]

12. Bester, K. Polycyclic musks in the ruhr catchment area-Transport, discharges of waste water, and transformations of HHCB, AHTN and HHCB-Lactone. J. Environ. Monit. 2005, 7, 43-51. [CrossRef]

13. Bester, K.; Hühnerfuss, H.; Lange, W.; Rimkus, G.G.; Theobald, N. Results of non target screening of lipophilic organic pollutants in the german bight. II: Polycyclic musk fragrances. Water Res. 1998, 32, 1857-1863. [CrossRef]

14. Sumner, N.R.; Guitart, C.; Fuentes, G.; Readman, J.W. Inputs and distributions of synthetic musk fragrances in an estuarine and coastal environment: A Case Study. Environ. Pollut. 2010, 158, 215-222. [CrossRef] [PubMed]

15. Lee, I.S.; Kim, U.J.; Oh, J.E.; Choi, M.; Hwang, D.W. Comprehensive monitoring of synthetic musk compounds from freshwater to coastal environments in Korea: With consideration of ecological concerns and bioaccumulation. Sci. Total Environ. 2014, 470-471, 1502-1508. [CrossRef]

16. Vallecillos, L.; Borrull, F.; Pocurull, E. On-Line coupling of solid-phase extraction to gas chromatography-mass spectrometry to determine musk fragrances in wastewater. J. Chromatogr. A 2014, 1364, 1-11. [CrossRef]

17. Fromme, H.; Otto, T.; Pilz, K. Polycyclic musk fragrances in different environmental compartments in Berlin (Germany). Water Res. 2001, 35, 121-128. [CrossRef] 
18. Heberer, T.; Gramer, S.; Stan, H.J. Occurrence and distribution of organic contaminants in the aquatic system in Berlin. Part III: Determination of synthetic musks in Berlin Surface Water Applying Solid-Phase Microextraction (SPME) and Gas ChromatographyMass Spectrometry (GC-MS). Acta Hydrochim. Hydrobiol. 1999, 27, 150-156. [CrossRef]

19. Balk, F.; Ford, R.A. Environmental risk assessment for the polycyclic musks, AHTN and HHCB. II. Effect assessment and risk characterisation. Toxicol. Lett. 1999, 111, 81-94. [CrossRef]

20. Gatermann, R.; Hellou, J.; Hühnerfuss, H.; Rimkus, G.; Zitko, V. Polycyclic and nitro musks in the environment: A comparison between Canadian and European Aquatic Biota. Chemosphere 1999, 38, 3431-3441. [CrossRef]

21. Kannan, K.; Reiner, J.L.; Se, H.Y.; Perrotta, E.E.; Tao, L.; Johnson-Restrepo, B.; Rodan, B.D. Polycyclic musk compounds in higher trophic level aquatic organisms and humans from the United States. Chemosphere 2005, 61, 693-700. [CrossRef]

22. Nakata, H. Occurrence of synthetic musk fragrances in marine mammals and sharks from Japanese Coastal Waters. Environ. Sci. Technol. 2005, 39, 3430-3434. [CrossRef]

23. Nakata, H.; Sasaki, H.; Takemura, A.; Yoshioka, M.; Tanabe, S.; Kannan, K. Bioaccumulation, temporal trend, and geographical distribution of synthetic musks in the marine environment. Environ. Sci. Technol. 2007, 41, 2216-2222. [CrossRef]

24. Shek, W.M.; Murphy, M.B.; Lam, J.C.W.; Lam, P.K.S. Polycyclic musks in Green-Lipped Mussels (Perna viridis) from Hong Kong. Mar. Pollut. Bull. 2008, 57, 373-380. [CrossRef] [PubMed]

25. Reiner, J.L.; Kannan, K. Polycyclic musks in water, sediment, and fishes from the Upper Hudson River, New York, USA. Water Air Soil Pollut. 2011, 214, 335-342. [CrossRef]

26. Kang, C.S.; Lee, J.H.; Kim, S.K.; Lee, K.T.; Lee, J.S.; Park, P.S.; Yun, S.H.; Kannan, K.; Yoo, Y.W.; Ha, J.Y.; et al. Polybrominated diphenyl ethers and synthetic musks in umbilical cord serum, maternal serum, and breast milk from Seoul, South Korea. Chemosphere 2010, 80, 116-122. [CrossRef]

27. Yin, J.; Wang, H.; Zhang, J.; Zhou, N.; Gao, F.; Wu, Y.; Xiang, J.; Shao, B. The occurrence of synthetic musks in human breast milk in Sichuan, China. Chemosphere 2012, 87, 1018-1023. [CrossRef] [PubMed]

28. Balk, F.; Ford, R.A. Environmental risk assessment for the polycyclic musks AHTN and HHCB in the EU: I. Fate and exposure assessment. Toxicol. Lett. 1999, 111, 57-79. [CrossRef]

29. Luckenbach, T.; Corsi, I.; Epel, D. Fatal attraction: Synthetic musk fragrances compromise multixenobiotic defense systems in mussels. Comp. Study 2004, 58, 215-219. [CrossRef]

30. Yamauchi, R.; Ishibashi, H.; Hirano, M.; Mori, T.; Kim, J.W.; Arizono, K. Effects of synthetic polycyclic musks on estrogen receptor, Vitellogenin, Pregnane X Receptor, and Cytochrome P450 3A Gene Expression in the Livers of Male Medaka (Oryzias latipes). Aquat. Toxicol. 2008, 90, 261-268. [CrossRef] [PubMed]

31. Ehiguese, F.O.; Fernandez, M.d.C.C.; Lara-Martín, P.A.; Martín-Díaz, M.L.; Araújo, C.V.M. Avoidance behaviour of the shrimp Palaemon varians regarding a contaminant gradient of galaxolide and tonalide in seawater. Chemosphere 2019, 232, 113-120. [CrossRef]

32. Ehiguese, F.O.; Alam, M.R.; Pintado-Herrera, M.G.; Araújo, C.V.M.; Martin-Diaz, M.L. Potential of environmental concentrations of the musks galaxolide and tonalide to induce oxidative stress and genotoxicity in the marine environment. Mar. Environ. Res. 2020, 160, 105019. [CrossRef]

33. Breitholtz, M.; Wollenberger, L.; Dinan, L. Effects of four synthetic musks on the life cycle of the harpacticoid copepod Nitocra spinipes. Aquat. Toxicol. 2003, 63, 103-118. [CrossRef]

34. Wollenberger, L.; Breitholtz, M.; Kusk, K.O.; Bengtsson, B.E. Inhibition of larval development of the marine copepod Acartia tonsa by four synthetic musk substances. Sci. Total Environ. 2003, 305, 53-64. [CrossRef]

35. Gooding, M.P.; Newton, T.J.; Bartsch, M.R.; Hornbuckle, K.C. Toxicity of synthetic musks to early life stages of the freshwater mussel Lampsilis cardium. Arch. Environ. Contam. Toxicol. 2006, 51, 549-558. [CrossRef] [PubMed]

36. Pedersen, S.; Selck, H.; Salvito, D.; Forbes, V. Effects of the polycyclic musk HHCB on individual- and population-level endpoints in Potamopyrgus antipodarum. Ecotoxicol. Environ. Saf. 2009, 72, 1190-1199. [CrossRef]

37. Chen, C.; Zhou, Q.; Liu, S.; Xiu, Z. Acute toxicity, biochemical and gene expression responses of the earthworm Eisenia fetida Exposed to Polycyclic Musks. Chemosphere 2011, 83, 1147-1154. [CrossRef] [PubMed]

38. Chen, F.; Gao, J.; Zhou, Q. Toxicity Assessment of Simulated Urban Runoff Containing Polycyclic Musks and Cadmium in Carassius auratus Using Oxidative Stress Biomarkers. Environ. Pollut. 2012, 162, 91-97. [CrossRef]

39. Zhang, L.; An, J.; Zhou, Q. Single and Joint Effects of HHCB and Cadmium on Zebrafish (Danio rerio) in feculent water containing bedloads. Front. Environ. Sci. Eng. China 2012, 6, 360-372. [CrossRef]

40. Parolini, M.; Magni, S.; Traversi, I.; Villa, S.; Finizio, A.; Binelli, A. Environmentally relevant concentrations of Galaxolide (HHCB) and Tonalide (AHTN) induced oxidative and genetic damage in Dreissena polymorpha. J. Hazard. Mater. 2015, 285, 1-10. [CrossRef] [PubMed]

41. Ehiguese, F.O.; Rodgers, M.L.; Araújo, C.V.M.; Griffitt, R.J.; Martin-Diaz, M.L. Galaxolide and tonalide modulate neuroendocrine activity in marine species from two taxonomic groups. Environ. Res. 2021, 196, 110960. [CrossRef]

42. Matozzo, V.; Ballarin, L.; Marin, M.G. In vitro effects of tributyltin on functional responses of haemocytes in the Clam Tapes philippinarum. Appl. Organomet. Chem. 2002, 16, 169-174. [CrossRef]

43. Matozzo, V.; Costa Devoti, A.; Marin, M.G. Immunotoxic Effects of triclosan in the clam Ruditapes philippinarum. Ecotoxicology 2012, 21, 66-74. [CrossRef] [PubMed]

44. Matozzo, V.; Rova, S.; Marin, M.G. The nonsteroidal anti-inflammatory drug, ibuprofen, affects the immune parameters in the clam Ruditapes philippinarum. Mar. Environ. Res. 2012, 79, 116-121. [CrossRef] [PubMed] 
45. Matozzo, V.; Formenti, A.; Donadello, G.; Marin, M.G. A multi-biomarker approach to assess effects of triclosan in the clam Ruditapes philippinarum. Mar. Environ. Res. 2012, 74, 40-46. [CrossRef]

46. Matozzo, V.; Ballarin, L.; Marin, M.G. Exposure of the clam Tapes philippinarum to 4-Nonylphenol: Changes in anti-oxidant enzyme activities and re-burrowing capability. Mar. Pollut. Bull. 2004, 48, 563-571. [CrossRef] [PubMed]

47. Santovito, G.; Boldrin, F.; Irato, P. Metal and metallothionein distribution in different tissues of the mediterranean clam Venerupis philippinarum during copper treatment and detoxification. Comp. Biochem. Physiol. Part C Toxicol. Pharmacol. 2015, 174-175, 46-53. [CrossRef]

48. Jiang, W.; Fang, J.; Gao, Y.; Du, M.; Fang, J.; Wang, X.; Li, F.; Lin, F.; Jiang, Z. Biomarkers responses in manila clam, Ruditapes philippinarum after single and combined exposure to mercury and benzo[a]pyrene. Comp. Biochem. Physiol. Part C Toxicol. Pharmacol. 2019, 220, 1-8. [CrossRef]

49. Trombini, C.; Hampel, M.; Blasco, J. Assessing the effect of human pharmaceuticals (carbamazepine, diclofenac and ibuprofen) on the marine clam Ruditapes philippinarum: An integrative and multibiomarker approach. Aquat. Toxicol. 2019, 208, 146-156. [CrossRef] [PubMed]

50. Marisa, I.; Asnicar, D.; Matozzo, V.; Martucci, A.; Finos, L.; Marin, M.G. Toxicological effects and bioaccumulation of fullerene C60 (FC60) in the Marine Bivalve Ruditapes philippinarum. Ecotoxicol. Environ. Saf. 2021, 207, 111560. [CrossRef]

51. Parolini, M.; Binelli, A.; Cogni, D.; Provini, A. Multi-biomarker approach for the evaluation of the cyto-genotoxicity of paracetamol on the Zebra Mussel (Dreissena polymorpha). Chemosphere 2010, 79, 489-498. [CrossRef]

52. Matozzo, V.; Giacomazzo, M.; Finos, L.; Marin, M.G.; Bargelloni, L.; Milan, M. Can ecological history influence immunomarker responses and antioxidant enzyme activities in bivalves that have been experimentally exposed to contaminants? A new subject for discussion in "Eco-Immunology" studies. Fish Shellfish Immunol. 2013, 35, 126-135. [CrossRef]

53. Parolini, M.; Pedriali, A.; Binelli, A. Chemical and biomarker responses for site-specific quality assessment of the lake maggiore (Northern Italy). Environ. Sci. Pollut. Res. 2013, 20, 5545-5557. [CrossRef]

54. Marisa, I.; Matozzo, V.; Munari, M.; Binelli, A.; Parolini, M.; Martucci, A.; Franceschinis, E.; Brianese, N.; Marin, M.G. In Vivo exposure of the marine clam Ruditapes philippinarum to zinc oxide nanoparticles: Responses in gills, digestive gland and haemolymph. Environ. Sci. Pollut. Res. 2016, 23, 15275-15293. [CrossRef] [PubMed]

55. Marisa, I.; Matozzo, V.; Martucci, A.; Franceschinis, E.; Brianese, N.; Marin, M.G. Bioaccumulation and effects of titanium dioxide nanoparticles and bulk in the clam Ruditapes philippinarum. Mar. Environ. Res. 2018, 136, 179-189. [CrossRef]

56. Matozzo, V.; Marin, M.G.; Cima, F.; Ballarin, L. First evidence of cell division in circulating haemocytes from the manila clam Tapes philippinarum. Cell Biol. Int. 2008, 32, 865-868. [CrossRef]

57. Matozzo, V.; da Ros, L.; Ballarin, L.; Meneghetti, F.; Gabriella Marin, M. Functional responses of haemocytes in the Clam Tapes philippinarum from the Lagoon of Venice: Fishing impact and seasonal variations. Can. J. Fish. Aquat. Sci. 2003. [CrossRef]

58. Fisher, W.S.; Oliver, L.M.; Edwards, P.E. Hematologic and serologic variability of Eastern Oysters from Apalachicola Bay, Florida. J. Shellfish Res. 1996, 15, 554-564.

59. Bradford, M.M. A Rapid and sensitive method for the quantitation of microgram quantities of protein utilizing the principle of protein-dye binding. Anal. Biochem. 1976, 72, 248-254. [CrossRef]

60. Crapo, J.D.; McCord, J.M.; Fridovich, I. Preparation and assay of superioxide dismutases. Methods Enzymol. 1978, 53, 382-393. [CrossRef]

61. Aebi, H. Catalase in Vitro. Methods Enzymol. 1984, 105, 121-126. [CrossRef] [PubMed]

62. Smith, I.K.; Vierheller, T.L.; Thorne, C.A. Assay of glutathione reductase in crude tissue homogenates using 5,5'-Dithiobis(2Nitrobenzoic Acid). Anal. Biochem. 1988, 175, 408-413. [CrossRef]

63. Habig, W.H.; Pabst, M.J.; Jakoby, W.B. Glutathione S Transferases. The first enzymatic step in mercapturic acid formation. J. Biol. Chem. 1974, 249, 7130-7139. [CrossRef]

64. Mecocci, P.; Fanó, G.; Fulle, S.; MacGarvey, U.; Shinobu, L.; Polidori, M.C.; Cherubini, A.; Vecchiet, J.; Senin, U.; Beal, M.F. Age-dependent increases in oxidative damage to DNA, lipids, and proteins in human skeletal muscle. Free Radic. Biol. Med. 1999, 26, 303-308. [CrossRef]

65. Ellman, G.L.; Courtney, K.D.; Andres, V.; Featherstone, R.M. A new and rapid colorimetric determination of acetylcholinesterase activity. Biochem. Pharmacol. 1961, 7, 88-95. [CrossRef]

66. Escartín, E.; Porte, C. The use of cholinesterase and carboxylesterase activities from Mytilus galloprovincialis in pollution monitoring. Environ. Toxicol. Chem. 1997, 16, 2090-2095. [CrossRef]

67. Matozzo, V.; Gagné, F. Immunotoxicology approaches in ecotoxicology: Lessons from mollusks. In Lessons in Immunity: From Single-Cell Organisms to Mammals; Elsevier Inc.: Amsterdam, The Netherlands, 2016; pp. 29-51, ISBN 9780128032527.

68. Galloway, T.S.; Depledge, M.H. Immunotoxicity in invertebrates: Measurement and ecotoxicological relevance. Ecotoxicology 2001, 10, 5-23. [CrossRef] [PubMed]

69. Kaloyianni, M.; Dailianis, S.; Chrisikopoulou, E.; Zannou, A.; Koutsogiannaki, S.; Alamdari, D.H.; Koliakos, G.; Dimitriadis, V.K. Oxidative Effects of inorganic and organic contaminants on haemolymph of mussels. Comp. Biochem. Physiol. C Toxicol. Pharmacol. 2009, 149, 631-639. [CrossRef] [PubMed]

70. Oliver, L.M.; Fisher, W.S. Appraisal of prospective bivalve immunomarkers. Biomarkers 1999, 4, 510-530.

71. Pipe, R.K.; Coles, J.A. Environmental contaminants influencing immunefunction in marine bivalve molluscs. Fish Shellfish Immunol. 1995, 5, 581-595. [CrossRef]

72. Munari, M.; Matozzo, V.; Foschi, J.; Cattani, O.; Serrazanetti, G.P.; Marin, M.G. Effects of high temperatures on functional responses of haemocytes in the clam Chamelea gallina. Fish Shellfish Immunol. 2007, 22, 98-114. [CrossRef] [PubMed] 
73. Milan, M.; Pauletto, M.; Patarnello, T.; Bargelloni, L.; Marin, M.G.; Matozzo, V. Gene transcription and biomarker responses in the clam Ruditapes philippinarum after exposure to ibuprofen. Aquat. Toxicol. 2013, 126, 17-29. [CrossRef]

74. Livingstone, D.R. Contaminant-stimulated reactive oxygen species production and oxidative damage in aquatic organisms. Mar. Pollut. Bull. 2001, 42, 656-666. [CrossRef]

75. Valavanidis, A.; Vlahogianni, T.; Dassenakis, M.; Scoullos, M. Molecular biomarkers of oxidative stress in aquatic organisms in relation to toxic environmental pollutants. Ecotoxicol. Environ. Saf. 2006, 64, 178-189. [CrossRef]

76. Valbonesi, P.; Sartor, G.; Fabbri, E. Characterization of cholinesterase activity in three bivalves inhabiting the North Adriatic Sea and their possible use as sentinel organisms for biosurveillance programmes. Sci. Total Environ. 2003, 312, 79-88. [CrossRef]

77. Wilson, B.W. Cholinesterases. In Hayes' Handbook of Pesticide Toxicology; Elsevier Inc.: Amsterdam, The Netherlands, 2010; pp. 1457-1478, ISBN 9780123743671.

78. Sandahl, J.F.; Jenkins, J.J. Pacific Steelhead (Oncorhynchus mykiss) Exposed to Chlorpyrifos: Benchmark Concentration Estimates for Acetylcholinesterase Inhibition. Environ. Toxicol. Chem. 2002, 21, 2452-2458. [CrossRef]

79. Brahma, N.; Gupta, A. Acute toxicity of lead in fresh water bivalves Lamellidens jenkinsianus obesa and Parreysia (Parreysia) corrugata with Evaluation of sublethal effects on acetylcholinesterase and catalase activity, lipid peroxidation, and behavior. Ecotoxicol. Environ. Saf. 2020, 189, 109939. [CrossRef] [PubMed]

80. Fulton, M.H.; Key, P.B. Acetylcholinesterase inhibition in estuarine fish and invertebrates as an indicator of organophosphorus insecticide exposure and effects. Environ. Toxicol. Chem. 2001, 20, 37. [CrossRef] [PubMed]

81. Hook, S.E.; Gallagher, E.P.; Batley, G.E. The role of biomarkers in the assessment of aquatic ecosystem health. Integr. Environ. Assess. Manag. 2014, 10, 327-341. [CrossRef] [PubMed]

82. Ozkan, D.; Dagdeviren, M.; Katalay, S.; Guner, A.; Yavaşoğlu, N.Ü.K. Multi-biomarker responses after exposure to pollution in the Mediterranean mussels (Mytilus galloprovincialis L.) in the Aegean Coast of Turkey. Bull. Environ. Contam. Toxicol. 2017, 98, 46-52. [CrossRef]

83. Ghedira, J.; Jebali, J.; Bouraoui, Z.; Banni, M.; Chouba, L.; Boussetta, H. Acute effects of chlorpyryphos-ethyl and secondary treated effluents on acetylcholinesterase and butyrylcholinesterase activities in Carcinus maenas. J. Environ. Sci. 2009, 21, 1467-1472. [CrossRef]

84. Kolarich, D.; Weber, A.; Pabst, M.; Stadlmann, J.; Teschner, W.; Ehrlich, H.; Schwarz, H.-P.; Altmann, F. Glycoproteomic characterization of butyrylcholinesterase from human plasma. Proteomics 2008, 8, 254-263. [CrossRef]

85. John, H.; Balszuweit, F.; Kehe, K.; Worek, F.; Thiermann, H. Toxicokinetics of chemical warfare agents: Nerve agents and vesicants. In Handbook of Toxicology of Chemical Warfare Agents; Elsevier Inc.: Amsterdam, The Netherlands, 2009; pp. 755-790. ISBN 9780123744845.

86. Bonacci, S.; Corsi, I.; Focardi, S. Cholinesterase activities in the adductor muscle of the antarctic scallop Adamussium colbecki. Antarct. Sci. 2006, 18, 15-22. [CrossRef]

87. Perić, L.; Ribarić, L.; Nerlović, V. Cholinesterase activity in the tissues of bivalves Noah's Ark Shell (Arca noae) and warty venus (Venus verrucosa): Characterisation and in vitro sensitivity to organophosphorous pesticide trichlorfon. Comp. Biochem. Physiol. B Biochem. Mol. Biol. 2013, 165, 243-249. [CrossRef] [PubMed] 